\title{
Antifunctionality in language change ${ }^{1}$
}

\author{
Pieter A. M. Seuren ${ }^{a} \&$ Camiel Hamans ${ }^{b}$ \\ ${ }^{a}$ Max Planck Institute for Psycholinguistics, Nijmegen \\ ${ }^{b}$ Dutch Delegation PES-group, European Parliament, Strasbourg
}

The main thesis of the article is that language change is only partially subject to criteria of functionality and that, as a rule, opposing forces are also at work which often correlate directly with psychological and sociopsychological parameters reflecting themselves in all areas of linguistic competence. We sketch a complex interplay of horizontal versus vertical, deliberate versus nondeliberate, functional versus antifunctional linguistic changes, which, through a variety of processes have an effect upon the languages concerned, whether in the lexicon, the grammar, the phonology or the phonetics. Despite the overall unclarity regarding the notion of functionality in language, there are clear cases of both functionality and antifunctionality. Antifunctionality is deliberately striven for by groups of speakers who wish to distinguish themselves from other groups, for whatever reason. Antifunctionality, however, also occurs as a, probably unwanted, result of syntactic change in the acquisition process by young or adult language learners. The example is discussed of V-clustering through Predicate Raising in German and Dutch, a process that started during the early Middle Ages and was highly functional as long as it occurred on a limited scale but became antifunctional as it pervaded the entire complementation system of these languages.

Keywords: analogy, functionalism, functionality, grammaticalisation, language acquisition, language change, reanalysis, Predicate Raising, Subject Raising

\footnotetext{
${ }^{1}$ This article was presented at the 41st Annual Meeting of the Societas Linguistica Europaea held at the University of Bologna/Forlí, 18-20 September 2008. We must acknowledge our debt to two referees, who made useful suggestions for improvement. Gunter Senft directed our attention to Konrad's translation of the Chanson de Roland and also helped us in tracing references. All remaining errors, shortcomings and inadequacies are, of course, our own responsibility.
} 


\section{Introduction}

In this article we try to find some certainties in a sea of uncertainties. The uncertainties are centered on the notion of functionality in language in general and its role in language change and language contact in particular. Since language has a purpose, both as a social institution and as a cognitive and physiological faculty, it is subject to functionality constraints at different levels. In a general sense, therefore, functionality as a concept in linguistic theorising is indispensable. Yet when we try to come down to specifics, the concept proves highly elusive. In part, this elusiveness derives from the fact that there is still widespread uncertainty as to what purpose or purposes are served by language. Most writers implicitly assume that the primary function of language is to enable a speaker to transfer information to an audience, or to "express thoughts", or even (Chomsky) to conduct inner talk. One often finds the anodyne term communication as an excuse for the underlying lack of specificity. Yet when one reflects on what it is to commit a speech act, one will see that the primary function of language consists in the establishing of socially binding commitments or appeals with regard to given propositions (see Seuren 2009: ch. 4). Clearly, if one does not know what a system is made for, one is hardly in a position to specify what will and what will not make it more useful.

In the same way, linguists are still, despite the vast literature on the subject, very much in the dark about what is good and what is bad for the functioning of language in speech (see Newmeyer 2003 and the ensuing discussion in Language 2005). This is due in the first place to the fact that, as yet, too little is known, or anyway generally agreed upon, about the sort of system underlying and driving linguistic performance and the concomitant question of the storage and functioning of any given language variety or set of language varieties in the brain. One can say, of course, that what contributes to a proper functioning of language is functional and what is counterproductive is antifunctional. But this remains an empty phrase as long as one does not specify how and for what purpose language functions. As long as that is not done, one is hardly in a position to specify what will improve and what will damage linguistic performance.

Yet despite this conceptual near-vacuum, some clarity can be created. We know that language is often used for the marking of social status or group loyalty or disloyalty, in addition to what we consider its primary purpose, that of establishing socially binding commitments or appeals with regard to given propositions. We also know that the primary purpose of language is achieved 
through a group-specific mechanism consisting in principle of a lexicon, a grammar and a phonology, which together enable a competent speaker to express any given intended meaning in terms of some perceptible medium, and a competent or near-competent listener to reconstruct the intended meaning from the perceptible material offered.

Well then, if the term functional is taken, as it usually is, in the mechanistic sense of covering everything that contributes to a maximally efficient expression of the intended meaning and an equally maximally efficient comprehension of the uttered message, as well as to a maximally efficient language acquisition process, then phenomena that are indicative of a speaker's wish to mark his or her social status or group loyalty or disloyalty fall outside the scope of functionality criteria and may have antifunctional effects. If, however, one reckons the marking of group loyalties and of differences in social prestige among the functions language has to fulfill (as one suspects some authors, in particular Haspelmath, of doing), then not only are phenomena of the kind described above fully functional, but it also becomes difficult to see what could possibly be left that would qualify as antifunctional. The notion of antifunctionality would thereby become vacuous. In this respect, language is not too different from dress norms.

In the present article, we take the term functionality in the mechanistic sense. That is, we take it to be synonymous with efficiency with regard to the primary function of language in speech, namely the establishing of socially binding commitments or appeals with regard to given propositions, as well as to the process of language acquisition. Since the marking of group loyalties or of differences in social prestige is not reckoned to belong to the primary function of language or to play a part in processes of language acquisition, efficiency with regard to these aspects of language and speech is not reckoned to be covered by the concept of functionality in the strictly linguistic sense. Analogously, the term antifunctionality is considered to be synonymous with counterproductivity with regard to the primary function of language in speech and to language acquisition as described above.

Yet under this definition, there is still room for contrary indications. For example, what is functional for the speaker may be antifunctional for the listener. It would seem, in particular, that the former is helped by the observance of rules of lexical and grammatical encoding - Haspelmath's "economy maxim" (1999b: 1055) - whereas the latter is rather helped by the avoidance of encoding processes, that is, by semantic transparency (Haspelmath's "clarity"; ibid.). Is memory storage more or less functional than rule-governed patterning? Is maintenance of redundancy (as in the German case system) functional or 
antifunctional? We do not know - at least not beyond an intuitive, and hence primitive, level of judgement.

Even so, however, we sometimes come across cases of functionality, or antifunctionality, that are so immediately obvious that one feels entitled to say that any theory of functionality that claims adequacy must at least account for them in a proper way. Such clear cases serve as a preliminary yardstick for any theory of functionality and it is such cases that we will try to fall back on in our effort to gain some certainty in the sea of uncertainties.

Then, our knowledge of how exactly language change proceeds and what motivates it is equally deficient. We know, of course, that all languages change as long as they are used in a speech community and we have been very good, over the past two centuries, at actually registering or reconstructing specific linguistic changes, not only from a macrohistorical (comparative-philological) but also from a microhistorical point of view (case studies in dialectology and sociolinguistics). But we are largely ignorant of how new language learners organise, or reorganise, their growing linguistic competence and under what conditions or why they modify their competence later on. Not that such questions have not been broached in the literature. On the contrary, many bookshelves can be filled with writings on these matters. But much as this literature has helped us to marshal our thoughts on the subject, there has been relatively little substantive progress.

One has tried to locate the origin of linguistic change in the process of language acquisition, mostly by young children but often also, in a secondary sense, by adults already in command of a first language. We will call this vertical change. ${ }^{2}$ The key concepts, in this respect, are reanalysis (the learner assigns to otherwise identical utterances structures and rules that differ from those assigned by the original speakers, with further, sometimes drastic, consequences for the grammar as a whole) and grammaticalisation (the learner stereotypes certain frequently occurring 'free' creations into grammatical constructions, whereby the original free words are typically semantically bleached and phonologically reduced).

Vertical change, however, cannot be solely responsible for language change, because vertical change is restricted to individuals (unless it occurs on a massive scale), whereas languages exist as part of social reality. A second factor is, therefore, required - the factor of spread or propagation of an existing, marked

\footnotetext{
${ }^{2}$ This concept of vertical change is comparable, but probably not identical, to Andersen's innovative reanalysis (Andersen 2001, 2006).
} 
linguistic variant or of an innovation or modification through all or part of the speech community in question, depending on the extent to which the marked variant or the innovation or modification is accepted as belonging to the linguistic norm. Let us call that horizontal change. ${ }^{3}$ An isolated vertical change will not affect the language as a social institution unless it is transmuted into a horizontal change with sufficient numerical clout and social acceptance to have an impact on the social reality of the language in question (cf. Andersen 2006). Horizontal change may originate from a vertical change, but also from a spontaneous innovation or modification introduced into the language by mature speakers, or from close contact with one or more other languages.

Horizontal change is a necessary phase in any language change that originates from one or a few individuals and is not already widely spread because of massively occurring vertical change. An innovation does not become part of a language or language variety unless it has a certain spread among the community of speakers. An immediate corollary, as is neatly explained and illustrated with a wealth of examples in Thomason (2007), is resistance to change. When the resistance goes right through the entire language community, there will be no change at all or the change will be short-lived. But what is found more often is that a change that is already on its way in certain parts of the community is, usually on grounds of group pride, resisted by other parts, resulting in increased internal variation in the language as a whole.

In this connection it is perhaps relevant to observe that, psychologically speaking, acceptance of a spreading change in fact consists in a refusal on the part of listeners to correct what must strike them initially as a violation of the prevailing norm. When we speak of listeners refusing to correct what they must perceive as an error, we take into account that these listeners will, perhaps subconsciously, stand by their refusal and will manifest their attitude in the utterances they produce themselves.

Horizontal changes, like the innovations underlying them, that are to do with the lexicon or with the phonetic realisation of sound units are sometimes, but not always, deliberate or at least open to possible awareness. When they are, the acceptance or rejection of such lexical or phonetic innovations at this stage of the change process can be raised to a level of explicit consciousness without too much effort (see Thomason 2007 for a clear and sensible exposé). Not so, however, for innovations (and possible corresponding horizontal spread) in the more abstract areas of syntactic or morphological structure. As is illustrated in

${ }^{3}$ Simply called "change" by Andersen (2001, 2006). 
section 3, reanalysis or the assignment of a new structure to certain well-formed word sequences, is much more likely to take place well below any threshold of consciousness or awareness. Therefore, the horizontal spread of that type of innovation will normally escape the conscious attention of speakers. Accordingly, one would expect it to be the case that "resistance to lexical borrowing has been more widely noted than resistance to structural interference" (Thomason 2007: 49), because one hardly notes resistance to something that one is not aware of one way or another. ${ }^{4}$

This much seems incontrovertible, though, as a matter of principle, we cannot exclude other possible sources of language change or other possible channels through which it may take place. After all, the power and importance of the social factor in language studies did not emerge until about a century ago. Before that time, there was a general blindness to the social dimension of language. We, in our day, may be equally blind to still unknown dimensions or parameters.

How does the criterion of functionality fare in the context of horizontal versus vertical and deliberate versus nondeliberate change in lexicon, grammar, phonology and phonetics? Labov, in his seminal article (2007), equates what we call vertical change with "transmission" and our horizontal change with "diffusion", positing that transmission processes underlie Schleicher's Family Tree Model of linguistic change, whereas diffusion is taken to underlie the Wave Model (Schmidt 1872). ${ }^{5}$ But he fails to bring the functionality criterion

${ }^{4}$ This difference in possible raising to awareness may well be related to the notion of control gate, at which the speaker is able to monitor, and if necessary to correct, the output of a given component of his or her own symbolisation machine (Seuren 2004: 59, 2009: 253-254). Lexical choice and phonetic output are typically subject to such output control and corrections are quickly made by the substitution of single units. Surface structures are also presumably checked by an output control gate, but here corrections require a total reprocessing.

${ }^{5}$ To us, this position seems at least tendentious but more probably just wrong. The present authors feel that Schleicher's Family Tree Model is primarily based on the presumption of standardised, national languages, while Schmidt's Wave Model, with the concomitant notion of isoglosses, is primarily justified on grounds of strictly vernacular speech without taking into account any supraregional, standardised norm. The two models can be reconciled only in the context of a theory that analyses and describes not only the social and interactional status of different language varieties (dialects, sociolects) within a speech community but also how and why the umbrella notion of 'standard language' can be seen to be valid despite internal variability. Equally necessary 
into the equation. (Nor does he mention the distinction between deliberate and nondeliberate change.) Haspelmath (1999a) and Croft (2000), for not altogether transparent reasons (see Andersen 2006), seek a parallel with evolution theory (not unlike August Schleicher during the nineteenth century). For Haspelmath, language change is largely restricted to horizontal change and requires structural variation in all areas of grammar, leading to dominant frequency of the more useful of linguistic structures ("user optimality" as a parallel to the survival-of-the-fittest principle), and hence to the eventual obligatoriness of the more useful and hence more frequent variants. Croft (2000) disagrees. For him, vertical change is a parallel of change taking place in biological reproduction and is largely of a functional nature, while horizontal change - the analog of the struggle for survival in biological nature - is exclusively determined by social, not by functional, factors - that is, by factors of social identification (Croft 2000: $32,38,39,54,178)$.

Seiler (2006) criticises both. He criticises Haspelmath for his notional unclarity and his neglect of the vertical transmission parameter. Just as Andersen (2006) does, he criticises Croft for the empirical inadequacy of his theory (as Croft's data are mostly restricted to cases presented in the sociolinguistic literature). And indeed, if a language learner can be taken to grow unwittingly an improved grammar with enhanced functionality, why should the same enhanced functionality be ruled out, as a matter of principle, as a factor in the horizontal spread of the improvement made (or of any functional innovation introduced outside the vertical transmission chain)? For one thing, it may happen that frequently occurring sentence structures in a given language simply cry out for reanalysis, so that large numbers of language learners will exhibit the change and thus make for sufficient horizontal spread. An example of such an unconscious language change is discussed in section 3. At the conscious level of what Thomason (2007) calls 'deliberate change', the examples abound. Acronyms, for example, such as NATO for North Atlantic Treaty Organisation, arguably owe their rapid spread mainly to their highly functional saving of energy in speaking and writing, though they become an obstacle to efficient comprehension when they get too thick on the ground.

is a theory of how an internally variable conglomerate of linguistic varieties can be taken to be stored in individual minds in the form of 'linguistic competence'. In such a theory, genealogical language trees represent standardised languages, not the complex fabric of interwoven dialectal variants, while 'waves' must be taken to spread not only through geographical but also through sociological and interactional space (see Seuren 1982). 
Analogy, or the regularising of grammar or of phonological form, is a frequent cause of language change (one which Croft inexplicably excludes), both vertically and horizontally and both deliberately and nondeliberately. Analogy is highly functional when it generalises through the language as a whole, as is (almost) the case in the following stock example from the comparativephilology literature. The Latin nominatives amor ('love'), honor ('honour'), arbor ('tree'), etc., with their genitives and further declined forms amoris, etc., honoris, etc., arboris, etc., were originally amos-amosis, etc., honos-honosis, etc., arbos-arbosis, etc. The intervocalic $-s$ - in the declined forms then became $-r$ - (so-called 'rhotacism', as also in ausosa > aurora 'dawn'). The paradigm thus became amos-amoris, etc., honos-honoris, etc., arbos-arboris, etc. By analogy the nominative case was then 'regularised', giving the paradigm amor-amoris, etc., honor-honoris, etc., arbor-arboris, etc. It is not known whether this analogical process started, say, in the Latin as spoken by the lower classes or in a particular area, but no such assumption need to be made to understand why speakers of Latin regularised the case and number paradigm of the nouns in question, as the change was obviously functional. This analogical regularisation was well-nigh complete throughout the language, and thus highly functional, though there was incidental resistance to this change, associated with upperclass, literary Latin, where, in particular, the nominative honos ('honour') remained in use for a long time.

One would expect analogy to be functional by definition, since it creates regularity. Yet this is not so, the main reason being that analogical processes more often than not affect only a part of the lexicon or grammar. An example of an antifunctional, because not general, analogical process is the following. In standard Dutch, a large number of verbs with stem-vowel $-\varepsilon$ - or -I- followed by a liquid or nasal and possibly one further consonant have a strong past participle with - o-vocalism and an -en ending:

zwerven ('wander') - gezworven
verwerven ('acquire') - verworven
werven ('recruit, enlist') - geworven
werpen ('throw') - geworpen
bergen ('salvage') - geborgen
helpen ('help') - geholpen
zwellen ('swell') - gezwollen
delven ('delve') - gedolven
schenden ('violate') - geschonden
melken ('milk'v.) - gemolken
zwemmen ('swim') - gezwommen

zwerven ('wander') - gezworven verwerven ('acquire') - verworven werven ('recruit, enlist') - geworven werpen ('throw') - geworpen bergen ('salvage') - geborgen helpen (help')-geholpen zwellen ('swell') - gezwollen delven ('delve') - gedolven schenden ('violate') - geschon
melken ('milk' v.) - gemolken zwemmen ('swim') - gezwommen

\author{
sterven ('die') - gestorven \\ bederven ('spoil') - bedorven \\ verderven ('corrupt morally') - verdorven \\ zenden ('send') - gezonden \\ verzwelgen ('swallow') - verzwolgen \\ winden ('wind') - gewonden \\ winnen ('win') - gewonnen \\ beginnen ('begin') - begonnen \\ binden ('bind') - gebonden \\ vinden ('find') - gevonden \\ verzinnen ('think up') - verzonnen
}


By contrast, many other such verbs (often etymological denominatives, though not recognised as such by Dutch speakers) have a (regular) weak past participle:

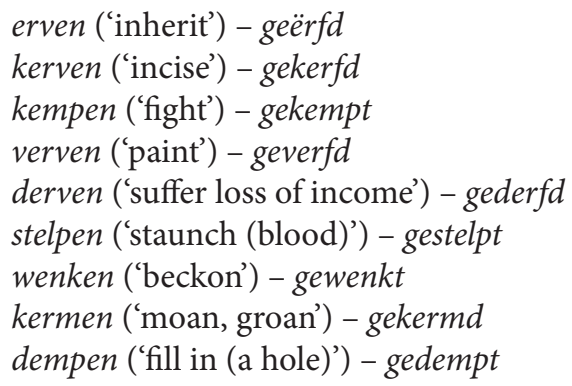

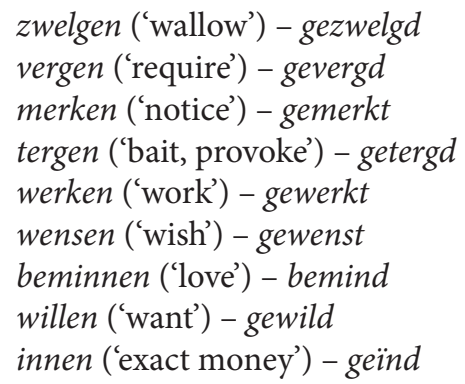

As a consequence, learners of Dutch, of whatever age, simply have to memorise which verb takes what - a perfect soil for arbitrary analogy processes. The point is that those deviations from the standard that are attested are entirely due to analogy either way, from the strong to the weak forms and from the weak to the strong forms. Their (partial) spread is merely due to linguistic insecurity of speakers, without any social force exerting an influence. One thus finds the standard forms gezwelgd ('wallowed') next to verzwolgen ('swallowed'), even though the latter is merely a compound (with the prefix ver-) of the former. No social-group symbolism is detectable here, as is confirmed by the major Dutch dictionaries. Or, to take another example, the rather widespread substandard deviation georven ('inherited') is in no way associated with substandard speakers' group pride. On the contrary, it rather puts such speakers to shame when they are corrected. Spreads of this nature seem entirely due to analogical processes that propagate themselves up to a point (like the phonological 'waves' described in Schmidt 1872), along with the presumption of linguistic authority on the part of certain members of the language community.

We thus have before our eyes a complex fabric of movements, factors, means and force fields whose mutual relations and interrelations are only partially clear. We see an interplay of horizontal versus vertical, deliberate versus nondeliberate, functional versus antifunctional linguistic changes, which, through a variety of processes, analogy being prominent among them, have an effect upon lexicon, grammar, phonology and phonetics.

Authors on the subject of language change often show a tendency to indulge in aprioristic, even dogmatic statements, leaving too little room for the rich variety of formal, psychological and ecological forces that may have an impact on a given language system. If anywhere it is here that one must keep an open eye for the rich environment in which every language system is created, maintained 
and modified on the one hand and the lack of clarity of our insight on the other. In the present article we do not intend to engage in the details of current discussions. Instead and, as far as possible, independently of current debates, we wish to call attention to the fact that language change, of whatever kind, is often antifunctional, in that it makes it more difficult or more energy-consuming to master the system and use it. If all language change were functional, languages would soon reach asymptotic heights of unparallelled efficiency. But that is not the impression one gets, no doubt because there are opposing forces at work, those that enhance functionality and those that diminish it, besides those that are functionally indifferent.

\section{Antifunctional horizontal change}

That deliberate horizontal change is often antifunctional is relatively uncontroversial. It is implied in Haspelmath's maxim of extravagance, which says that people often "talk in such a way that [they] are noticed" (Haspelmath 1999b: 1055). Such desire to be noticed often runs counter to the measure of cost-effectiveness: being 'different' does not, on the whole, come without cost. It is also implied, though in a different way, in Croft's contention that horizontal change is per se insensitive to functionality criteria, which opens the gate to functional, antifunctional and a-functional changes. Though Croft is simply wrong and Haspelmath provides only a partial glimpse of what is going on, both are right in that they allow the social dimension into the picture. Functionality criteria would have free play in a utopian society or contact situation without any group interests and where everybody is in perfect harmony with everybody else. In actual fact, however, speakers often have an interest in setting their group or subgroup off from others and one obvious way of doing so is to make their group language more difficult to master. As soon as such (socio)psychological phenomena reach critical mass in the language of a group, they become part of the linguistic landscape. Horizontal change often, but not always, results from group pride (nationality, ethnicity, class, language/dialect, religion, etc.), and it often, but not always, means greater complexity and hence loss of functionality: the harder it is to master your group language, the more quickly 'impostors' will fall through.

Examples abound. Academically trained speakers of English are anxious to maintain the Latin plural morpheme $-i$ in the appropriate scholarly Latin loanwords: rhombi, loci, bulbi, (but not ${ }^{*}$ circi, as circus is not a scholarly word). 
This helps to unmask cultural impostors talking of we ignorami (indeed). Some Dutch aristocrats (or would-be members of that class) emphasise their social position by speaking not of [heli'kəptər], as everyone else in the Netherlands does, but of hélicoptère, pronounced the French way. The same people make a point of using substandard douwen for standard duwen ('push'), substandard zouwen for standard zouden ('would'), substandard Leien for standard Leiden (name of the town), substandard zeien for standard zeiden ('said', past tense of say), substandard motten for standard moeten ('must'), substandard kommen for standard komen ('come') - all, of course, pronounced in such a way that there will be no confusion with real substandard speakers. The point of this borrowing from substandard varieties is the aristocrats' wish to emphasise that they are so much above the norm that they can afford borrowing from below it. ${ }^{6}$ In a similar fashion, the Dutch aristocracy likes to make use of spurious strong past-participle forms, such as gebreeën for gebreid ('knitted'), georven for geërfd ('inherited'), knowing well that such forms are current among uneducated speakers. Thus, in the mouths of Dutch aristocrats, the use of nonstandard georven expresses these speakers' wish to set themselves apart from the rest of society, whereas, as has been said above, no such effect is intended by substandard or uneducated speakers using the same form.

As regards the spurious strong form gebreeën ('knitted'), it should be observed that, in Dutch, verbs written with the stem vowel -ei- have a weak (regular) paradigm, with the past tense ending in -te/de and the past participle in $-t / d$, as in standard gebreid, whereas verbs written with the homophonous but etymologically different stem vowel $-i j$ - (both are pronounced $\left[-\varepsilon^{\mathrm{y}}-\right]$, with " $\varepsilon$ " as in English bet) have an irregular (strong) verbal paradigm, with the past tense stem vowel $-e(e)$ - and the past participle in $-e C(C) e n$, as in blijven-gebleven ('stay', 'remain') - a process known as the ablaut system, which is responsible

${ }^{6}$ Curiously, aristocrats, though using motten for moeten ('must'), do so only in the plural, not in the singular, where they still use the standard moet, even though substandard speakers keep the paradigm regular and say mot. The aristocrats thus make their grammar more complex by disturbing the regularity of the verbal paradigm of motten. (For substandard kommen instead of standard komen ('come') they do use the paradigmatically regular kom, but that is standard anyway.) Why our upper-class friends fail to extend their lower-class borrowing of motten to the singular form, is unknown. One should note that these phenomena are instances of fully conscious, somewhat manneristic, borrowing from what is considered an inferior sociolect. Would-be aristocrats, of course, do not borrow from substandard varieties but copy the usage of the group they wish to be associated with. 
for the irregular strong-verb paradigms. The ablaut system, however, stopped being productive centuries ago: the class of strong verbs is now closed and no new strong verbs should, therefore, come into use. The form gebreeën cuts through this regularity and thus complicates the pattern. A parallel process is observed in the form gezeken, from the verb zeiken (literally 'urinate', hence 'be a nuisance', 'insist unnecessarily'). This irregular (strong) past participle was introduced some fifty years ago by upper-class university students, consciously following the breien-gebreeën pattern. The use of gezeken is now commonly accepted, though only in the meaning 'insisted unnecessarily'.

On the other side of the Atlantic it has been observed (Weinreich et al. 1968) that, during a certain period, young native speakers of the Martha's Vineyard variety of American English asserted their local origin (as against Yankee newcomers) by centralising the vowel quality of the diphthongs $\left[\mathrm{a}^{\mathrm{y}}\right]$ and $\left[\mathrm{a}^{\mathrm{w}}\right]$ to $\left[\varepsilon^{\mathrm{y}}\right]$ and $\left[\varnothing^{\mathrm{w}}\right]$, respectively. One may assume that this started off as a largely subconscious accommodation with regard to those older speakers the young speakers felt a basic solidarity with, even though it would have been easy to raise the difference to awareness, for example by malicious mimicking.

In Britain, the now standard loss of plural marking for English nouns denoting certain species of animals (fish, deer, lion, but not, for example, plural ${ }^{\star}$ dove) started as a mannerism in British hunting jargon, where these words were treated as a specific class of mass nouns. From there it spread to the language of farmers, ending up as a feature of the standard language. Again, although MRI scans would presumably have shown some extra activity (N400 effects; Hagoort \& Van Berkum 2007) in the brains of those who were first exposed to this change, this is not enough to speak of deliberate change.

More likely to be deliberate are the following cases, which take us back to the Netherlands and Belgium. During the 1990s, successful Dutch businessmen, followed by those who wanted to be associated with them, took to re-introducing the antiquated second-person personal pronoun gij (corresponding to English thou or ye) into their speech, thereby changing their group language (the change did not make it to the standard language and has meanwhile died out as too many people thought this mannerism silly). In some, especially Belgian, dialects of Dutch, the doublet plural forms artikels and artikelen (both 'articles'), which are semantically indifferent in the standard language, are used differentially: artikels (with the more scholarly plural ending $-s$ ) for publications in a journal or newspaper and artikelen (with the popular plural ending -en) in the sense of 'objects' such as are found in shops.

Mixed-base numeral systems often bear testimony to group allegiance 
(Bauer 2004). The numeral system of standard French is basically decimal, but it has vestiges of a vigesimal system (soixante-dix for 'seventy', quatre-vingt for 'eighty'). In many regional varieties of French, the numeral system has been streamlined by the introduction of septante for 'seventy' and huitante for 'eighty'. The resistance put up by standard French against the obviously functional innovation of septante and huitante is no doubt to be traced to national Gallic pride, as the vigesimal system is Gallic in origin.

Idiosyncratic 'reinforcers' (for lack of a better term), serving to push adjectival property expressions to unknown heights of intensity, are popular, especially among teenagers. ${ }^{7}$ In Dutch we find beregoed (literally 'boarlike good') and in German scheißgut ('shit-good'), both for something like 'damn good'. Dutch again has onmachtig mooi (literally 'unmightily beautiful', corresponding to something like 'unspeakably beautiful'), while in German we find saublöd ('sow-stupid', 'damn stupid'). English has pitch-dark, stone-blind, stone-deaf and more. Since such 'reinforcing' expressions cannot be freely combined with other elements on a purely compositional basis but require special memorisation, their introduction is antifunctional from the point of view of language acquisition and encoding or decoding processes, but they serve the important social function of showing that the speaker belongs to a social group the listener may well crave membership of or admire the speaker for.

School teachers, authors and early grammarians have played their part too. As the German nominal case endings threatened to disappear, prescriptive grammarians and other authorities in the sixteenth, seventeenth and eighteenth centuries ensured that these endings were inculcated into young pupils at elementary and higher levels of education, with the result that the German case system is still fully alive (Von Polenz 1972: 99-100). (The same attempt was made in the Netherlands, but there the case endings were beyond rescue.) In large parts of the Netherlands (Hamans 2007), West-Germanic long [-ī-] developed into the diphthong $\left[-a^{y_{-}}\right]$, written $-i j-$, thus coalescing with original $\left[-\mathrm{a}^{\mathrm{y}}-\right]$, written -ei-. School teachers and others with linguistic authority, however, found that pronunciation uncivilised (Hellinga 1938) and in many areas they succeeded in getting people to change that pronunciation to the higher diphthong $\left[-\varepsilon^{y_{-}}\right]$, which is now standard (Hamans 2007, 2008). ${ }^{8}$

\footnotetext{
7 Sarah Thomason (2007: 44) rightly states: "Every generation of teenagers has its own slang vocabulary and every specialised field has its own technical lexicon, to take the most obvious examples."

${ }^{8}$ The diphthongisation of $-\bar{\imath}$ - into $-a y$ - and $-u$ - into $\left[-\varnothing^{\mathrm{y}}-\right]$, spelled $-u \dot{-}$ - in Dutch, is in
} 
Taboo words often resist regular phonological change. Consider, for example, the Dutch doublet piel versus pijl ([pīl] versus [p $\left.\varepsilon^{\mathrm{y}} \mathrm{l}\right]$, 'penis' versus 'arrow'), both derived from Latin pìlum ('spear'). Middle Dutch pìl should have become modern pijl for both meanings, but it only did so for the meaning 'arrow', the other meaning obviously being felt as specially marked. Similarly for the dialectal verb broeken (with stem vowel [u], 'enjoy', 'have sexual intercourse'), derived from West-Germanic brukan ('enjoy', 'use'). In this meaning, the stem vowel went through the regular change from $[\mathrm{u}]$ to $[\ddot{\mathrm{u}}]$ to $\left[\varnothing^{\mathrm{y}}\right]$, now found in standard Dutch gebruiken (with the intensifier prefix ge-). However, in the marked sexual meaning, this regular development was stopped by the taboo barrier, so that the word did not change at all and is still broeken, with stem vowel [u] (Hamans 1979).

In general, group loyalties and differences in social prestige make for a multiplication of variant forms, each variant marking a particular group. In all such cases, the innovations in question can be regarded as antifunctional because they either cut through regularities or increase the number of available variants, or both. In any case, they make it harder to acquire proper competence in the language or language variety at hand and, once that competence has been achieved, to use the system correctly, as more checks have to be carried out.

\section{Antifunctional vertical change: Predicate Raising in German and Dutch}

Most changes discussed so far come under the rubric of 'deliberate change', in the lax sense of 'subject to speaker's control and retrievable to some level of consciousness', which is why they can serve as tools in social scenarios or power games. They are, however, also superficial in the sense that they only skim the surface of the languages concerned: they only go skin-deep. This statement is, of course, theory-dependent. Those linguists who oppose what they see as 'abstract' theory and see languages as defined by heaps of statistical usage data without much structure or much grammatical depth, will be inclined to deny that the cases discussed above are 'superficial' and will wish to argue that all linguistic change is of that nature. The present authors do not belong to that school. For us, a grammar of a language is a socially accepted system for the

accordance with the theory developed by Labov, Yaeger \& Steiner (1972) regarding natural sound changes. 
conversion of given semantic thought inputs (consisting of a speech act operator and a propositional content) into recipes for well-defined acoustic or written outputs and to a large extent also vice versa, from phonologically interpreted input to thought content. That system is to a large extent formally definable and thus involves a certain measure of 'abstractness'. It is also largely inaccessible to awareness and must, therefore, be reconstructed by way of formulating and testing hypotheses. Changes that occur in that formal, or 'abstract', or introspectively inaccessible, realm are, in a sense, 'deeper' and harder to trace. Although, of course, they need a certain horizontal spread, without which the language as a piece of social reality will not be affected, that spread will hardly come about as a result of deliberate, conscious decisions by speakers. Perhaps the notion 'subconscious refusal to correct', discussed above, comes in useful here, but further psycholinguistic research should help us out.

In order to gain a clearer insight into what is at issue, we will now consider a case that has been investigated by the first author of the present article, the genesis of the Verb-clustering (Predicate Raising) process rampant in modern German and Dutch sentential complementation.

Let the point of departure be the process, or rule, of subject-to-object raising (SOR), also known as accusativus-cum-infinitivo. To show how SOR works we take the English sentence (1a), with the underlying propositional structure (1b), where speech act operator and tense are disregarded and where the underlying main-constituent order is taken to be Predicate-Subject-Object or VerbSubject-Object (VSO; McCawley 1970). The surface NP-VP pattern is assumed to come about as a result of the tense routine, whereby the finite tense operator (present or past) attracts the subject term but is itself lowered onto the predicate of the embedded main clause, which comes out as the superordinate VP in (1d) (Seuren 1996: 67-68):

(1) a. She let the man go.

b.

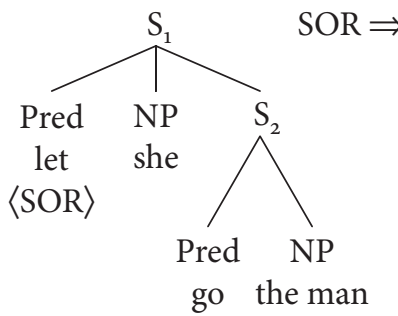

c.

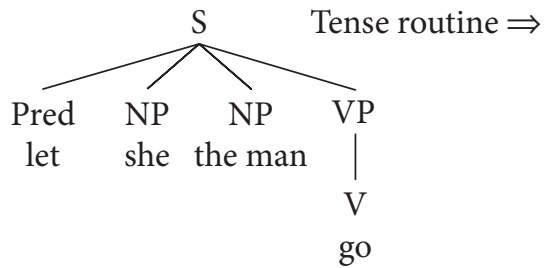




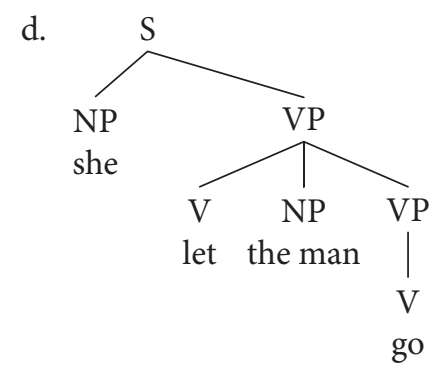

In the grammar of English complement clauses, the standard procedure is to apply cyclic SOR to the embedded object clause, in this case $\mathrm{S}_{2}$ in (1b). SOR is induced by the main predicate, in this case let (as indicated by the rule feature $\langle\mathrm{SOR}\rangle)$. SOR detaches the lower subject $\left(_{\mathrm{NP}}[\right.$ the man]) from its dominating $\mathrm{S}_{2}$-node and re-attaches it under the higher $\mathrm{S}_{1}$ in the position of its own $\mathrm{S}_{2}$, which is moved one position to the right and demoted to VP status (in virtue of the principle that every $S$ that loses its subject term is demoted to VP). In most cases, but not under let, the VP is preceded by the particle to. At the same time, the surface category $\mathrm{V}(\mathrm{erb})$ is assigned to the predicate go. The result is (1c). Tense routine gives the surface structure (1d).

Many of the world's languages have integrated this procedure into their grammar. The procedure itself may be deemed functional, in that it helps reduce multiple S-embeddings, incorporating to a certain extent the embedded object-S into the main or matrix structure. In doing so, the SOR-procedure keeps the constituents of the original embedded object-S together, even though the original subject term has now been taken out of the original object-S and has become a direct-object constituent of the superordinate S (marked by accusative case morphology in case-marking languages). Let us use the term contiguity principle for the phenomenon of the constituents of the original embedded object-S staying together in surface structure.

The Contiguity Principle apparently has some functional value in that it supports ready decoding (parsing) by listeners. A sentence with multiple object embeddings, such as (2), poses few problems for the listener, who needs a full propositional reconstruction of (2). (In a moment we will see the dramatic loss of decoding facility when the Contiguity Principle is given up.)

(2) She wanted John to tell Luke to let the dog fetch the newspaper.

In (2) we see not only that SOR has applied twice (on let and on want), but 
also that subject deletion (SD) has applied, on tell. SD is a further cyclic rule of English syntax, deleting the subject term of the embedded object-S (reducing the $S$ in question to VP) under conditions of referential or substitutional identity (marked by the variable symbol " $x$ ") with a nominal constituent of the superordinate $\mathrm{S}$. The particle to is added to the VP. Thus, sentence (3a), with underlying ( $3 \mathrm{~b})$, becomes $(3 \mathrm{c})$ and ultimately, by tense routine, $(3 \mathrm{~d})$ :

(3) a. John taught Luke to swim.

b. ${ }_{s}\left[\text { Pred }_{\text {Peach }}\right]_{N P}[\text { John }]_{N P}\left[\text { Luke }_{\mathrm{X}}\right]_{S}\left[{ }_{\text {Pred }}\left[\right.\right.$ swim $_{N \mathrm{NP}}\left[\right.$ Luke $\left.\left.\left._{\mathrm{x}}\right]\right]\right]$

c. ${ }_{s}\left[\right.$ Pred $[\text { teach }]_{\mathrm{NP}}[\mathrm{John}]_{\mathrm{NP}}[\text { Luke }]_{\mathrm{VP}}\left[\right.$ Particle $[\text { to }]_{\mathrm{V}}[$ swim $\left.\left.]\right]\right]$

d. ${ }_{s}\left[{ }_{\mathrm{NP}}[\mathrm{John}]_{\mathrm{VP}}\left[_{\mathrm{V}}[\text { taught }]_{\mathrm{NP}}[\text { Luke }]_{\mathrm{VP}}\left[\mathrm{Part}_{\mathrm{rar}}[\mathrm{to}]_{\mathrm{V}}[\mathrm{swim}]\right]\right]\right]$

Again, the Contiguity Principle is observed: the embedded object- $S_{S}[$ Pred $[$ swim] ${ }_{\mathrm{NP}}\left[\right.$ Luke $\left.\left._{\mathrm{x}}\right]\right]$ is not torn apart but is kept together. Only when SD is controlled by the higher subject, as in (4), is the Contiguity Principle violated:

(4) John wanted to leave.

Here, the original subject term of the object-S has disappeared and the controlling NP, ${ }_{\mathrm{NP}}[\mathrm{John}]$, is not contiguous with what remains of the object-S in surface structure, namely ${ }_{\mathrm{VP}}$ [to leave]. ${ }^{9}$

Now to Dutch and German, which we uncontroversially take to have been verb-final (SOV) languages at some traceable stage in the past (in subordinate and non-finite clauses they still are). The German and Dutch equivalents of (1a) will then have been, during the SOV period, $(5 \mathrm{a}, \mathrm{b})$ with the underlying propositional structures $(6 \mathrm{a}, \mathrm{b})$, respectively:

(5) a. Sie den Mann gehen ließ. (German)

b. Zij de man gaan liet. (Dutch)

9 There is a certain amount of literature on sentences of the type shown in (i), where the contiguity of $_{\mathrm{NP}}[\mathrm{Ann}]$ with ${ }_{\mathrm{VP}}$ [to be back soon] might trap the listener into taking Ann as the semantic subject term of the VP:

(i) John promised Ann to be back soon.

This is a problem only when syntax is not viewed as a system of formally defined rules but as a collection of more or less systematic devices for making sense of strings of words, which was how syntax was conceived of before the advent of structuralist linguistics. 
(6)

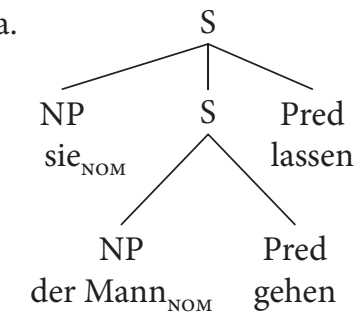

b.

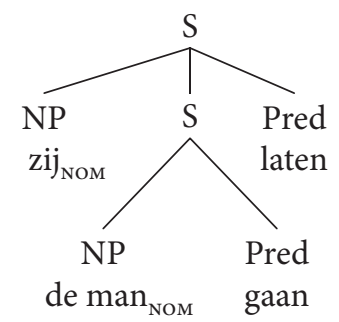

Here we see something remarkable: application of SOR does not affect word order, as is shown by $(7 \mathrm{a}, \mathrm{b})$, which fully observe the Contiguity Principle:

(7) a.

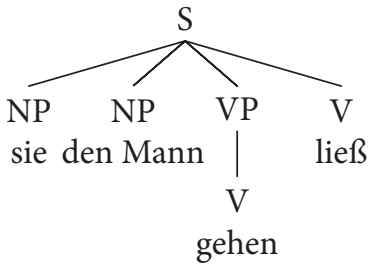

b.

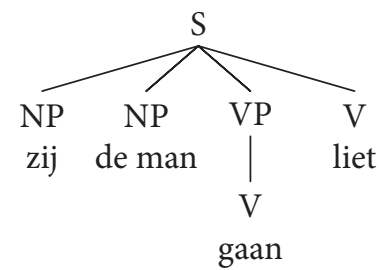

Were it not for the accusative case in German den Mann (and in Dutch equivalents from the time Dutch still marked its cases), one might even think that these sentences have kept their original underlying structure ${ }_{S}\left[{ }_{N P}[s i e]_{S}\left[{ }_{N P}[\right.\right.$ der Mann] ${ }_{\text {Pred }}[$ gehen $\left.]\right]_{\text {Pred }}[$ ließ $\left.]\right]$ or $_{S}\left[{ }_{N P}\left[\right.\right.$ zij] ${ }_{S}\left[{ }_{N P}[\text { de man }]_{\text {Pred }}[\text { gaan }]\right]_{\text {Pred }}[$ liet $\left.]\right]$. But this cannot be so, because there is a universal ban on non-finite verb forms occurring with true subjects, marked as such, as a result of which subjects have to be removed from embedded infinitives without finite tense one way or another (for example by SD or SOR). ${ }^{10}$ The accusatives in $(5 \mathrm{a}, \mathrm{b})$ are thus readily explained by the assumption of SOR, giving the structures $(7 \mathrm{a}, \mathrm{b})$.

${ }^{10}$ An apparent exception is found in Portuguese, which has so-called 'inflected infinitives' accompanied by subject terms in nominative case (Seuren 2004: 195-196), as in (i) or (ii):

(i) ...sem eu ver

... without I+NOM see

... without me seeing it

(ii) ... osem meninos verem

... without the children see+PLUR

... without the children seeing it

Here one must observe (a) that the morphological paradigm of these inflected infinitives is both poor and unique to this category and (b) that these infinitives are inflected 
The point is now that structures such as $(7 \mathrm{a}, \mathrm{b})$, with SOV word order, invite a reanalysis of the sequence ${ }_{V P}\left[{ }_{V}[\right.$ gehen $\left.]\right]+{ }_{V}[$ ließ $]$ or ${ }_{V P}\left[{ }_{V}[\right.$ gaan $\left.]\right]+{ }_{V}[$ liet $]$ in terms of a single composite verb: ${ }_{\mathrm{V}}\left[{ }_{\mathrm{V}}[\text { gehen }]_{\mathrm{V}}[\right.$ ließ] $]$ or $_{\mathrm{V}}{ }_{\mathrm{V}}[\text { gaan }]_{\mathrm{V}}[$ liet $\left.]\right]$. The resulting tree structures then look like $(8 \mathrm{a}, \mathrm{b})$, respectively, still without there being any change in the word order.

(8)

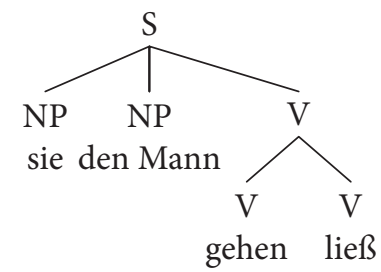

b.

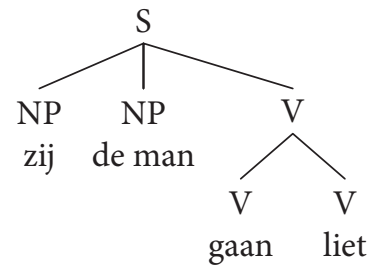

The main difference with $(7 \mathrm{a}, \mathrm{b})$ is that $(8 \mathrm{a}, \mathrm{b})$ contain one single V-constituent in the final position, which makes these structures immediately parsable in terms of SOV-structure. Speakers will even store such complex V-structures as single but composite verbs in the lexicon, as has happened in English, with the (unique) lexicalised form let go (as in I let go the rope, instead of the regularly formed $I$ let the rope go). Verbs meaning 'let' and especially those meaning 'make', 'cause' are primary candidates for such lexicalisation processes. Large numbers of languages have causative morphemes as part of their morphology, such as the Gothic causative infix - $i$-, as in tot-i-an ('dead' + 'cause' + infinitival suffix) leading to German töten ('kill') (Braune 1928: 107-108; García García 2005), or the Turkish causative infix -dIr-, as in bil-dir-mek ('know' + 'cause' + infinitival suffix, in fact meaning 'tell', 'inform').

Lexicons are all too eager to divest such forms of their grammatical structure and relexicalise them as single units. This has happened to English fell, derived from an Old-Germanic causative, as represented by Gothic fall-i-an ('fall' + 'cause' + infinitival suffix) but whose original grammatical relation to fall is no longer transparent to English speakers. (English has a still productive and very widespread null-suffix for 'causative', as in verbs like drop, sit, walk and numerous other examples, but causative umlaut, resulting from the post-stem infix - $i-$, has disappeared entirely from the language.) Malay has the by now fully lexicalised verb beritahu ('inform'), still transparently derived from beri

and thus not, or not clearly, non-finite. It would seem, therefore, that this Portuguese phenomenon represents a transitional form between full infinitival small clauses and embedding of finite clauses. In any case, the phenomenon deserves more attention than it has received so far. 
('give') and tahu ('know'): 'give-to-know'. The irregular phonology in Turkish forms like gös-ter-mek ('see' + 'make' + infinitival suffix, hence 'show'), from the stem gör- ('see'), or ge-tir-mek ('come' + 'make' + infinitival suffix, hence 'bring'), from the stem gel- ('come'), shows that relexicalisation has actually taken place. ${ }^{11}$ Given the massive drift towards relexicalisation of morphological causatives and admissives, it seems hard to deny that, in this respect at least, lexical storage must have a functional edge over grammatical composition-by-rule.

The structural reanalysis leading to V-clustering and illustrated in $(8 \mathrm{a}, \mathrm{b})$ is easily captured in terms of what is known as the rule of Predicate Raising or PR (McCawley 1968, Seuren 1972; for formal details, see Seuren 1996: 63-65, 2003: 251-266). In principle, PR consists in the adoption of the lower V- or Pred-constituent by the higher V- or Pred-constituent. A universal routine (Seuren 1996: 47-48) prunes the S- or VP-node dominating the lower V-or Pred-constituent and re-attaches any further constituents of the pruned $S$ or VP to the higher $S$, in their original order. When this procedure is applied to $(6 a, b)$, the result is $(8 \mathrm{a}, \mathrm{b})$. Whether the adoption process places the lower verb/predicate to the left or to the right of the higher verb/predicate, depends on the directionality parameter of the syntax concerned: if the syntax is left-branching, the lower $\mathrm{V}$ ends up on the left of the higher $\mathrm{V}$, and analogously when the syntax is defined for right-branching. Generally, SOV languages have a left-branching syntax, leading to the V-clusters shown in (8a,b). Since, however, modern Dutch syntax has switched over to right-branching, the modern Dutch word order is liet gaan, rather than gaan liet. In German, the left-branching order gehen ließ is still de rigueur (see Seuren 1996: ch. 5, 6, for extensive discussion).

We have assumed, so far, that, at some stage in their development, German and Dutch had SOR as their main strategy for removing lower subjects from their infinitival clauses. Is this assumption warranted? Our research on this issue is still in progress, but at the present stage we can report that the oldest written document in a Germanic language, Bishop Wulfila's fourth-century translation of the Bible from Greek into Gothic (the main East-Germanic language) shows

${ }^{11}$ These are thus clear and forceful counterexamples to Haspelmath's claim (Haspelmath 1999b) that grammaticalisation is irreversible. Similar counter-examples are presented by cases where recurrent parts of words were reanalysed as meaningful morphological elements in their own right and subsequently turned into words, such as the now perfectly normal German zig ('umpteen') from the recurrent ending in the German number names from 20 to 90, or English burger from the recurrent ending in words like hamburger, cheeseburger, etc. (see Ramat 1992, Hamans 1993, Norde 2006, Hamans, Fisiak \& Jahr 2009). 
that Gothic did indeed have SOR and had not yet taken to any verb-clustering strategy.

We consulted parts of Wulfila's translation of the Gospel of St. John in the New Testament. ${ }^{12}$ Wulfila's Gothic text is remarkable because it follows the original Greek word order almost one-to-one. One may conclude, therefore, that word order in Gothic was roughly as free as it was in the Koinē Greek of the New Testament and that Gothic was as much, or as little, V-final as Koinē Greek. Consider the following examples: ${ }^{13}$

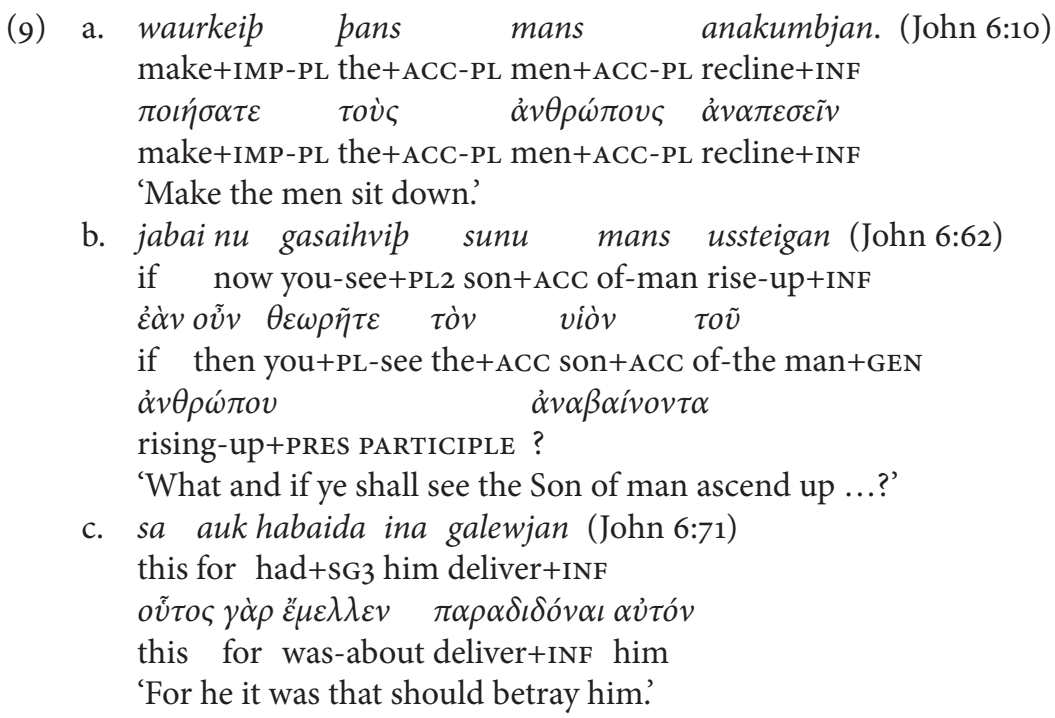

Example (9a) shows that the commanding imperative (causative) verb waurkeip (Eng. worketh) is separated from the lower infinitive anakumbjan ('recline') by the accusative NP pans mans ('the men'). This in itself is not sufficient to prove that no $\mathrm{V}$-clustering has occurred, since later rules may detach the imperative form from the cluster and place it in front position, as, indeed, happens in German and Dutch, which have Laßt die Männer sitzen and Laat de mannen zitten, respectively. But the word order observed is at least compatible with a SOR treatment.

\footnotetext{
${ }^{12}$ For verification, see www.wulfila.be/gothic/browse.

${ }^{13}$ The first line in each example is taken from Wulfila's text; the second line gives a word-by-word translation; the third and fourth lines give the corresponding Greek text with word-by-word translation; the last line gives the standard King James English translation.
} 
In example (9b) the commanding verb gasaihvip ('you+PL see') is again separated from the lower infinitive ussteigan ('rise up') by an intervening accusative NP, sunu mans ('the son of man'). Again, this does not, strictly speaking, prove that no V-clustering has occurred and SOR has applied, but one notices that (9b) is a subordinate clause, where any V2-constraint would have to be excluded. ${ }^{14}$ German and Dutch, with their V2-constraint for main clauses, have Ihr sehet des Menschen Sohn auffahren and Gij ziet de Mensenzoon opstijgen as main clauses, but wenn ihr denn des Menschen Sohn ${ }_{\mathrm{V}}[$ auffahren sehet] and als gij dan de Mensenzoon ${ }_{\mathrm{V}}$ [ziet opstijgen] as subordinate clauses - that is, with undeniable V-clustering. ${ }^{15}$ Example (9b) thus provides somewhat stronger evidence for an SOR-treatment than (9a).

Equally strong evidence is provided by example (9c), which is a main clause with the higher and the lower verb forms still separated by an intervening accusative, this time fulfilling the semantic role of object to the lower verb (the lower subject has been deleted by SD). One notes that the Greek original does have the two verb forms adjacent to each other, which would have been a reason for Wulfila to do the same in his Gothic rendering. But, apparently, his own Gothic would not let him do that, which to us means that V-clustering was not available to him. One may, of course, object that the word order in (9c) corresponds to what is found in modern German and Dutch, but the answer to that is that this

\footnotetext{
${ }^{14}$ For the non-initiated: by "V2-constraint" is meant the remarkable phenomenon that in German and Dutch affirmative main clauses the finite verb form is always the second main constituent. When a non-subject constituent is preposed as a result of topicalisation, the subject term hops across the finite verb form: Morgen werde ich kommen ('tomorrow I will come'). This phenomenon is sometimes reduced to a Celtic substrate: Celtic is a V-first language, but some Celtic languages (such as Breton; see Borsley \& Kathol 2000) also have obligatory topicalisation, with concomitant fronting, of some constituent in main clauses. If a VSO-order is assumed, this leads automatically to the V2-constraint for main clauses, which may have been adopted by German and Dutch for their SOV main clauses. However, such a theory is still very much open to debate, no matter how attractive it may be.

${ }^{15}$ Interestingly, Luther's sixteenth-century German translation has: wenn ihr denn sehen werdet des Menschen Sohn auffahren. Here, (left-branching) V-clustering has taken place only for sehen werdet ('see will'), but the infinitive auffahren ('ascend') has not yet been clustered, which means that SOR has still applied to the embedded object-S ${ }_{S}\left[_{N P}[\right.$ des Menschen Sohn] $]_{\mathrm{V}}[$ auffahren]]. Modern German has wenn ihr denn des Menschen Sohn auffahren seht (Deutsche Bibelstiftung 1978), with a fine left-branching V-cluster (see Seuren 1996: 271-280, 2003: 279-284).
} 
is only because of the V2-constraint for main clauses. In a subordinate clause, modern German and Dutch have no choice but to cluster when PR has applied. Since there clearly is nothing like a V2-constraint for Gothic main clauses, we must rule out that explanation and we may conclude, ceteris paribus, that Gothic had no V-clustering or predicate raising.

We now jump to the twelfth century, to one of the earliest substantive literary texts in German, the Middle-High-German translation by the German priest Konrad of the French epic poem Chanson de Roland, itself composed around 110o. The German text is found in Kartschoke (1993), who dates it around 1170 (Kartschoke 1993: 790-791). Here we have a very different situation as regards word-order constraints. The V2-constraint for main clauses is already in force, while subordinate clauses are $\mathrm{V}$-final, and V-clustering is normal though not exceptionless. ${ }^{16}$ Consider the following examples:

(10) a. Marsilie hiez komen sine man. (1. 568)

Marsilie let come his men

'Marsilie let his men come.'

b. Diu velt sâhen si glizzen. (1.634)

the fields saw they glitter

'They saw the fields glitter.'

c. Si hôrten die phaht lêren die edlen junchêrren. (11. 661-662)

they heard the law learn the noble squires

'They heard how the noble squires were learning the law'

d. Erhiezmir houbten zwêne mine man. (1.816)

he let to-me+DAT decapitate two of my men

'He had two of my men decapitated.'

e. Heiz brechen unde brennen ir vile unreine betehûs. (1l. 952-953)

let break and burn their many unclean houses of prayer

'Let their many unclean houses of prayer be destroyed and burnt.'

The picture is mixed here, and not in every respect as clear as we would like it to be. Sentence (10a) suggests V-clustering (hiez komen), though the

${ }^{16} \mathrm{~V}$-final in main clauses is still found, though exceptionally:

(i) Die christen sich ersluogen. (1.4751)

the christians themselves exhausted

'The Christians exhausted themselves.'

The same without V2 in:

(ii) Von gote daz kom. (1. 4750)

from god that came

'That came from God.' 
left-branching parameter would predict komen hiez. The order hiez komen is no doubt due to the V2-constraint, which wants the finite verb form (hiez) in second position. ${ }^{17}$ It is unclear, therefore, whether hiez komen does form a $\mathrm{V}$-cluster or whether it has been cut up by later transposition rules. The modern word order would be Marsilie hiez sine man komen, with the infinitive in final, and the finite verb form in second position. Perhaps this was the normal order but considerations of rhyme and rhythm interfered. In any case, (10a) is not compatible with an SOR-analysis.

Sentence (1ob) is a clear case of V2 and is compatible with V-clustering, in combination with an overall V-final constraint. Sentence (10c) again suggests V-clustering, though the NP die edlen junchêrren should then precede the infinitive lêren, giving the correct Modern Standard German Sie hörten die edlen Junker das Recht lernen, with V2 responsible for cutting up the underlying V-cluster. Note that the Modern Standard German word order in subordinate clauses would give ... daß sie die edlen Junker das Recht lernen hörten, with the V-cluster intact.

Example (1od) has the active infinitive houbten typical for V-clustering through PR, where passivisation is not marked. Take, for example, the normal German sentence Er ließ ihn töten, which is ambiguous between 'he let him kill' and 'he let him be killed'. (The dative mir is a so-called 'ethical dative', unknown in English but common in many other languages to express the speaker's involvement.) Similar phenomena are found in many other languages. French, for example, which also has V-clustering through PR for the causative verbs laisser ('let, allow') and faire ('cause, make'), has the same ambiguity in Il le laissait tuer.

Sentence (10e) is like (10a). If the text were written according to the syntax of Modern Standard German, one would have Heiz ir vile unreine betehûs brechen unde brennen. The V-clustering would be more obvious in a corresponding subordinate clause ... daz er ir vile unreine betehûs brechen unde brennen hiez. In fact, line 2422 reads:

(11) Hüetet, daz er iuch icht gesprechen mege. beware that he you aught appeal might 'Make sure that he can make no further demands'.

\footnotetext{
${ }^{17}$ In the theory of Semantic Syntax (Seuren 1996), (10a) is unproblematic. All that has to be assumed is that the late rule whereby komen should have been moved to the far right has been applied only in part, in that the movement has come to a halt before the final NP.
} 
Here, the that-clause clearly has a well-behaved final left-branching V-cluster.

The overall conclusion is that there are clear signs of V-clustering through $\mathrm{PR}$, though the V2-constraint and a corresponding relaxing of the SOV-order in main clauses tend to blur the picture. SOR is anyhow excluded.

So far, the argument has been that in the SOV-languages German and Old Dutch, functionality-driven reanalysis has led to the abandonment of SOR as a syntactic rule and the subsequent introduction of PR into their grammars a development that would make no sense in English, that language belonging to the group of V-initial or VSO-languages (McCawley 1970). But this hardly supports our thesis that language change is often antifunctional. More is thus needed if we wish to vindicate our position. And here it is.

Once the principle of V-clustering through Predicate Raising has made its appearance in the complementation grammar of a language, it will tend to spread through the grammar and the lexicon, thereby eliminating SOR altogether from the complementation grammar. In the cases observed so far, V-clustering through PR has been limited to fairly simple constructions with no more than one S-embedding. But as soon as the principle has caught hold, it may well burrow its way through the grammar by affecting more and more complementtaking verbs. This has indeed happened in German and Dutch, where a large proportion of the verbs that take either subject or object complementation now induce (obligatorily or optionally) the rule of Predicate Raising (Seuren 1985: 184, 2003: 267-269). Those that do not do so induce subject deletion (SD) to relieve their embedded Ss from their subject terms.

Although this cleans up the grammar and, to a large extent, also the lexicon, multiple applications of the process within one sentence has disastrous consequences for the listener, who now faces clauses with all nominal arguments arranged on the left and all verb forms on the right. Experience teaches that when there are more than two such nominal arguments and corresponding verb forms, the listener has to work very hard to associate the right NPs with the right verb forms. With four or more NPs and corresponding verb forms, the listener simply has to give up. Consider the following examples of subordinate clauses, which are, or should be, good German or Dutch but baffle any listener or reader:

(12) a. ... daß Johann den Mann den Hund die Zeitung holen lassen sehen ... that Johann the man the dog the newspaper fetch let see wollte wanted

'... that Johann wanted to see the man get the dog to fetch the newspaper' 
b. ... dat Jan de man de hond de krant wilde zien laten halen ... that Jan the man the dog the newspaper wanted see let fetch '... that Jan wanted to see the man get the dog to fetch the newspaper'

These monstrous sentences, which it takes pencil and paper to work out, are, of course, hardly ever produced outside the linguist's laboratory. Yet they simply follow from the generalised application of Predicate Raising, as is shown by the derivations (13a-e) and (14a-f). In (13) we see how repeated application of PR (with SD) has the effect of placing all NPs in parallel to the left and all verb forms, caught in a hierarchical V-cluster, to the right.

Let us assume German underlying word order to be SOV, with a corresponding left-branching syntax and hence left-branching V-clusters. ${ }^{18}$ The rules apply cyclically - that is, starting from the lowest embedded S and working their way up to the highest S-structure.

(13) a.

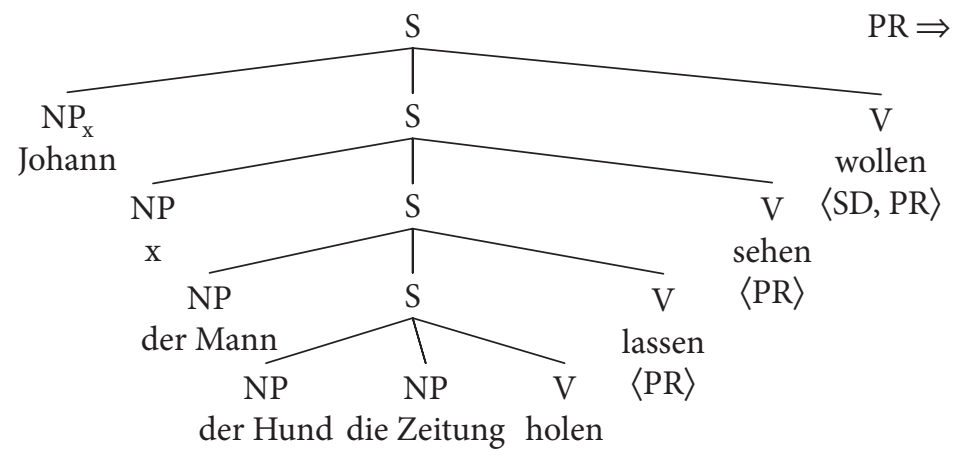

b.

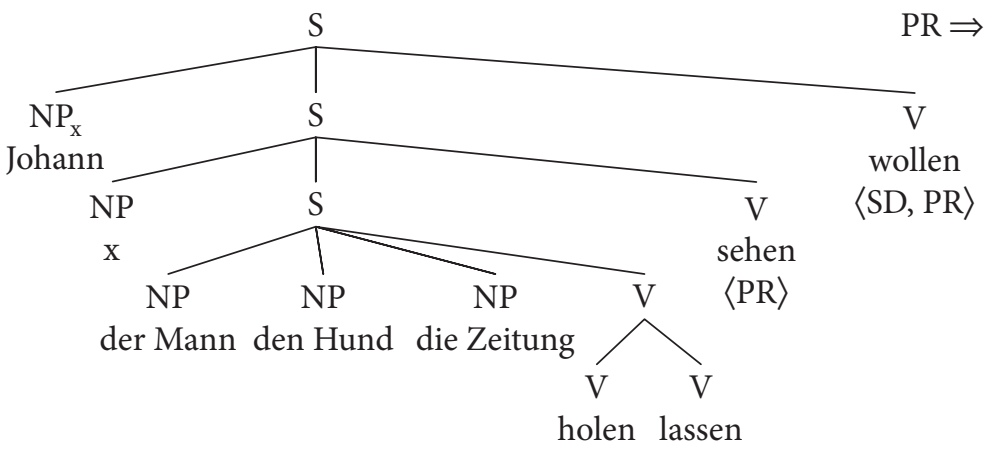

${ }^{18}$ In Seuren (1996: 270) it is argued that it is, on the whole, preferable to assume a VSO, and thus right-branching, underlying word order for German, but with a left-branching 
c.

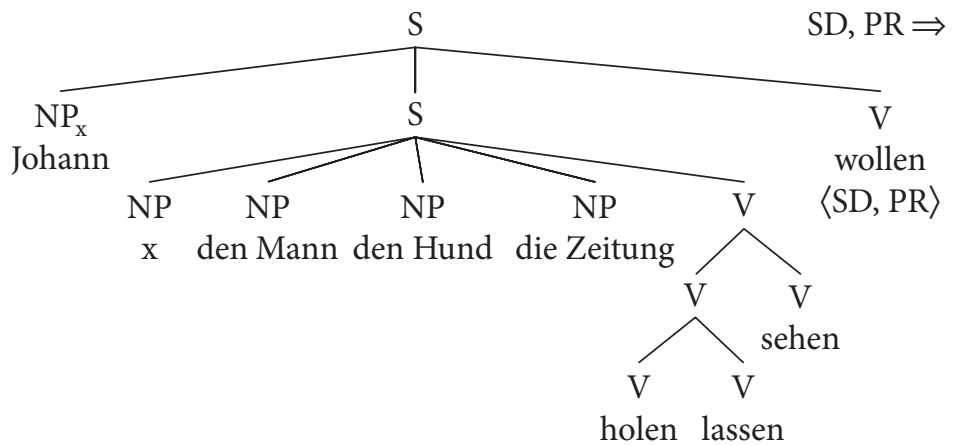

d.

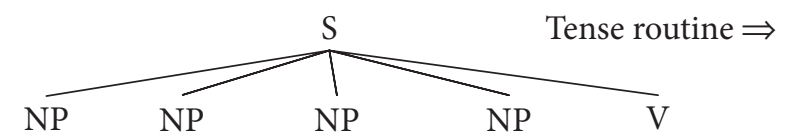

Johann den Mann den Hund die Zeitung

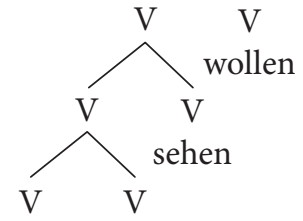

holen lassen

e.

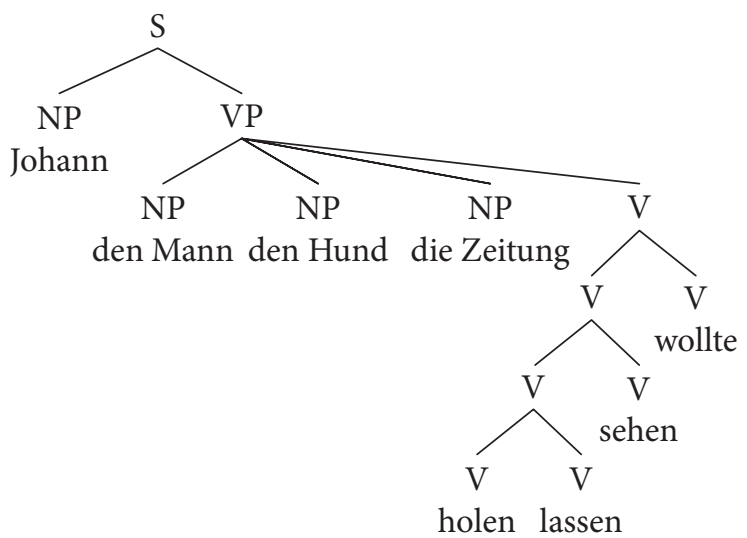

verbal syntax (V-clusters). Though we still stand by that view, it seems simpler, in the present, restricted, context, to ignore the wider aspects and assume verb-final underlying order for the whole of German syntax. All that is involved here is ease of exposition. 
Dutch follows an analogous procedure, albeit that the underlying word order is taken to be VSO, with a corresponding right-branching syntax (see n. 18). The different directionality of German and Dutch syntax thus explains the otherwise puzzling fact that the German clusters are (roughly speaking) the mirror image of the Dutch ones.

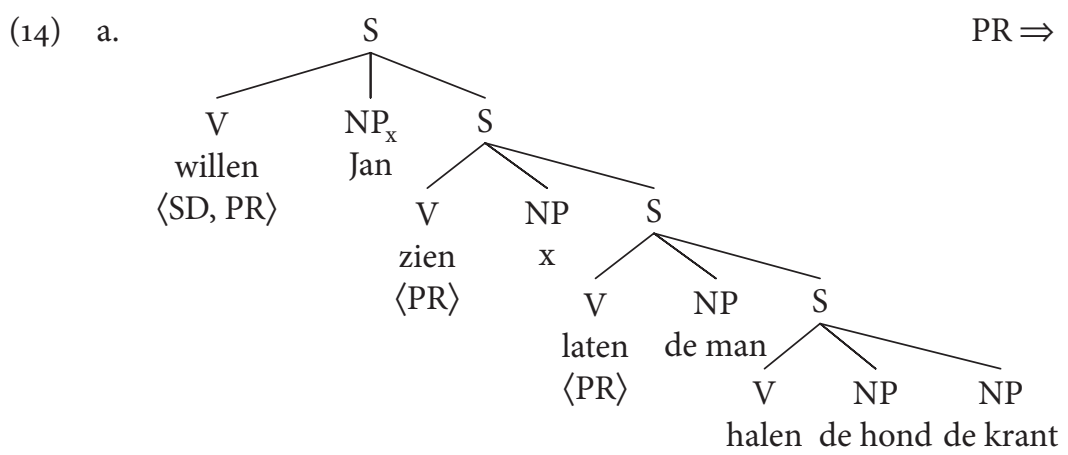

b.

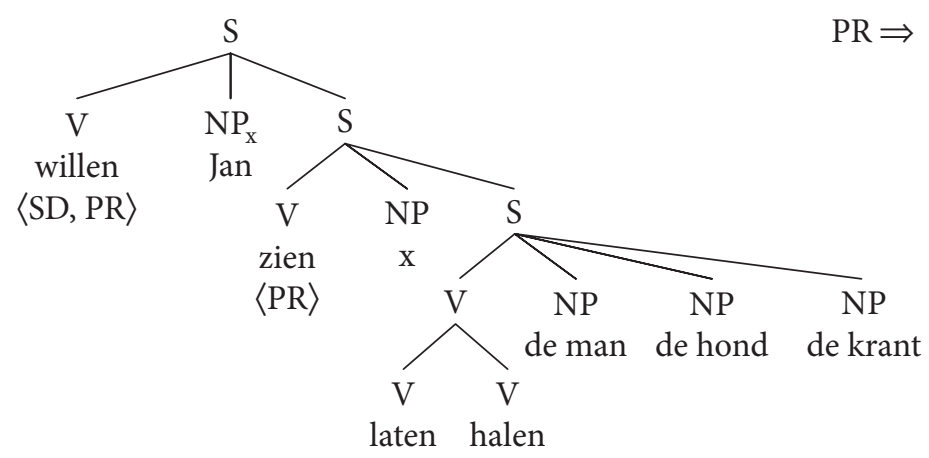

c.

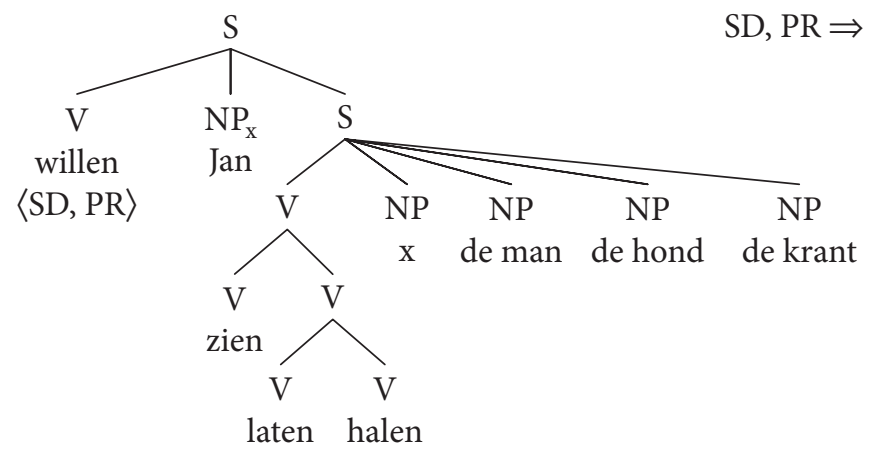


d.

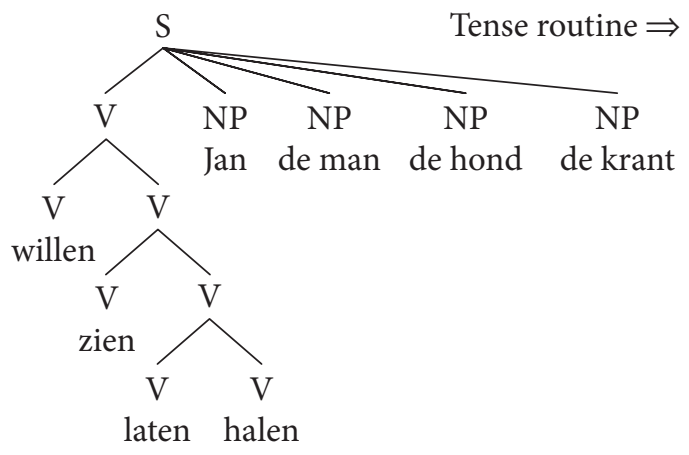

e.

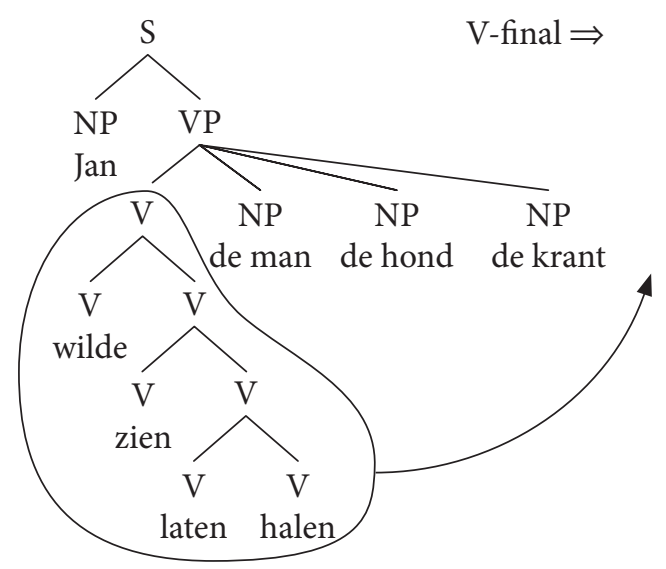

f.

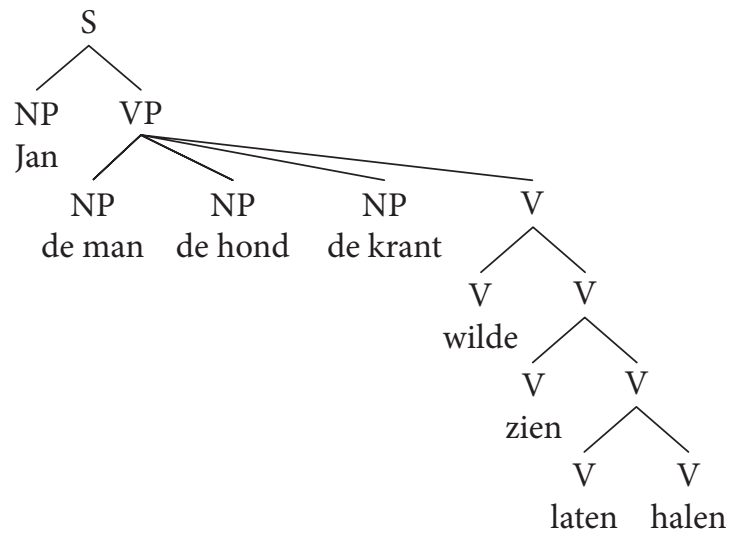


Repeated application of PR, in combination with multiple NPs, is thus seen to make sentences hard, if not impossible, to process. Dutch is even worse, in this respect, than German, because Dutch has crossing dependencies whereas German nests them, as is shown in (15a,b). In fact, Dutch seems to be the only language found so far that shows this extraordinary system of crossing dependencies. ${ }^{19}$ If this phenomenon is not antifunctional, nothing is!

(15) a. ... daß Johann den Mann den Hund die Zeitung holen lassen sehen wollte

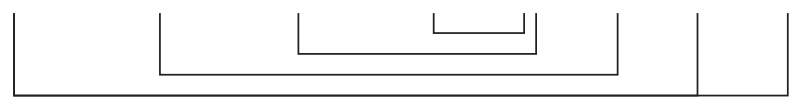

b. ... dat Jan de man de hond de krant wilde zien laten halen

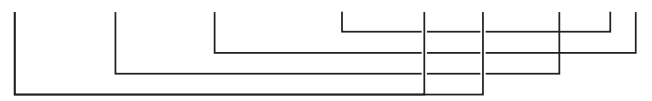

The processing problem seems to reside mainly in the number of NPs, and hence in the reconstructions of the semantic dependencies. Multiple embedding without an accumulation of NPs picked up from various embedded Ss does not provoke much of a processing problem, as one sees from $(16 \mathrm{a}, \mathrm{b})$, where no NP has to be related to any embedded S:

(16) a. ... daß ich stehen zu bleiben zu lernen versuchen wollte ... that I stand to stay to learn try wanted '... that I wanted to try to learn to stand still'

19 A different case of crossing dependencies, also unique or rare, is provided by classical Latin poetry. It is often said that Latin has free word order (which generativists have proposed to account for with the help of the not very inspiring notion of 'scrambling'). Here, too, what appears to be an innocuous licence when used with moderation, has turned into a highly artificial device when used to excess. Consider, for example, Horace, Carmina I, ix, 21-22:

Nunc et latentis proditor intimo / gratus puellae risus ab angulo.

'The lovely girl will tell by her ringing laugh / where she is hiding, deep in a secret nook.'

When properly arranged according to the Contiguity Principle, the lines will read:

Nunc et 〈repetatur〉 gratus risus latentis puellae proditor ab intimo angulo

now also $\langle$ must be sought $\rangle$ the lovely laughter of the hiding girl betraying (her) from a secret nook

Perhaps Horace wanted to puzzle his readers to the same extent that the young man addressed by the poem and looking for his girl friend hiding in a dark corner was supposed to have been puzzled. 

b. ... dat ik wilde proberen te leren te blijven staan ... that I wanted try to learn to stay stand '... that I wanted to try to learn to stand still'

Even so, speakers try to avoid such multiple V-clusters as much as possible. Dutch offers little relief in this respect, but German allows its speakers to say (17a, b or c), which are much preferred:

(17) a. ... daß ich zu lernen versuchen wollte, stehen $z$ u bleiben

b. ... daß ich versuchen wollte, stehen zu bleiben zu lernen

c. ... daß ich versuchen wollte zu lernen, stehen zu bleiben

The reason why German has more alternatives in such cases lies in the differing directionalities. In both German and Dutch, the verbs versuchen/proberen ('try') and lernen/leren ('learn') take only optional, not obligatory, PR. For Dutch this makes no difference in word order, owing to its right-branching syntax. In German, with its left-branching syntax, it does make a difference whether PR is or is not applied. In (17a), PR has not applied on lernen; in (17b) PR has not applied on versuchen; in (17c) PR has not applied on both lernen and versuchen.

When one compares the convoluted clauses (12a, b) with their English translation (as given there) one sees how much smoother the comprehension process is for the English version, which is readily interpreted, without any abnormal strain on the decoding process. Fortunately, many complement-taking German and Dutch verbs which induce PR do so optionally, leaving SD to remove the lower subject or allowing for a finite subordinate that-clause.

The picture that arises from the analysis given is startling. One sees that PR, when first introduced for a few prototypical verbs, such as causatives, appears to be conducive to more efficient production and comprehension processes. This is how PR is found in a large number of languages across the world: limited to a few complement-taking verbs, with frequent relexicalisation. But once PR is allowed to burrow its tunnels through grammar and lexicon as a whole, the process of V-clustering through Predicate Raising, so useful at first, suddenly turns upon itself and becomes highly antifunctional or dysfunctional - with Dutch as an extreme case. French, Italian, Japanese, Malay, Uto-Aztecan, Tagalog and countless other languages have allowed PR to enter the grammar but not to pervade it (Seuren 1972). These languages have kept V-clustering (through PR) in check, and have thus avoided dysfunctionality, by limiting the assignment of PR to just a few verbs, usually with the meaning 'cause' or 'allow'.

A different strategy is found in the French-based Creole of the island Mauritius. Here one finds (French-derived) PR on the verbs fer ('make', 'cause'), lessé 
('let'), tãdé (hear) and one or two other verbs (Seuren 1995: 557-562). However, PR is selectively applied for these verbs in Mauritian Creole (MC) sentences and the criterion appears to be the Contiguity Principle mentioned above (Seuren 1995: 562):

In the light of these considerations it looks as if MC has struck an optimal balance between the advantages and the disadvantages of the PR rule. It maximizes application of PR but only in those cases where the rule has no adverse effect on semantic transparency. There is thus a rationale behind the seemingly odd collection of conditions on this rule in MC. First note that semantic processing in $\mathrm{MC}$ is helped if the order subject-verb-object (SVO) is preserved, for the simple reason that the vast majority of sentences in $\mathrm{MC}$ have this order ... $\mathrm{S}<$ ubject $>\mathrm{R}<$ aising $>$ has the effect of maintaining SVO order, whereas PR (with right adoption) results in VSO for the embedded clause if that clause has both a subject and an object term. We now note that the conditions as stated above ensure that VSO never occurs in surface structure: when the lower V has more than one argument, PR does not apply and SR takes over, thus preserving the SVO order. But if the lower V has only one argument, then, as we have seen, PR is obligatory for the verbs in question when the original subject term is absent and the one argument in question is an original object term. The surface result is then that the object follows its verb, which is all right. Only when the one argument of the intransitive $S$ is the original subject of the lower $V$ will this subject follow its verb [...], so that PR leads to a VS order, but never to VSO [...]. In such cases, as has been said, PR is optional. The conditions for application of PR in MC thus seem to ensure pretty well that standard SVO constituent order is maintained, with the small exception of a possible VS order, which also occurs in surface structures, though less frequently.

Mauritian Creole thus provides a live demonstration of how the Contiguity Principle - important for rapid and efficient decoding - keeps the antifunctional effects of V-clustering through PR under control, with PR as the preferred option but filtered by a word-order constraint.

\section{Conclusion}

Much more research, not only of a linguistic but also of an experimental psycholinguistic nature, will be needed to complete the picture of the various kinds of change and their (anti)functionality and thus allow for further conclusions. As it is, we think we have put up a convincing argument that (a) nondeliberate change, taking place way below any threshold of possible awareness, is a power- 
ful factor in the development of language systems and (b) that antifunctionality plays an important role in language change, sometimes as a deliberately soughtafter effect, especially with groups of speakers who wish to set themselves off against other groups, and sometimes, mostly nondeliberately, as a factor blocking grammatical generalizations. Most importantly, however, we think we have shown that changes of whatever kind may seem both functional and innocuous when introduced for simple and relatively isolated cases but may turn out to be violently antifunctional when used on a larger scale. Our main example is Predicate Raising in Dutch and German; subsidiary examples are the use of acronyms in texts and word order scrambling in Latin poetry (see n. 19). In relation to Predicate Raising, the question of the horizontal spread of a nondeliberate change in the 'abstract' or formal syntax of a language now poses itself again. Since the change is nondeliberate and not retrievable to awareness, there can be no question of conscious or willed propagation through a population. One may think of gradually spreading reanalysis taking place on a massive scale and over a period of time in the minds of young language learners, but more research will have to be conducted to see if this is a viable hypothesis. Are there subconscious ways of adopting one's neighbour's grammar? We do not know. ${ }^{20}$

\section{References}

Andersen, Henning. 2001. Actualization and the (uni)directionality of change. In Henning Andersen, ed. Actualization: Linguistic change in progress. Amsterdam \& Philadelphia: John Benjamins, 225-248.

Andersen, Henning. 2006. Synchrony, diachrony and evolution. In Thomsen, ed. 59-90.

\footnotetext{
${ }^{20}$ We are grateful to one referee, who observed: "Actually, we do know, or there is at least strong evidence that subconsciously adopting one's neighbour's grammar is exactly what is going on. The evidence lies in the fact that there exists dialect geography. Dialect areas may be distinct from each other even in their properties of syntactic structure. The only way of understanding this fact is assuming that changes in syntactic structure originate in some areas at some time and then gradually spread across the landscape, from one village to the next. This process cannot be understood in terms of children's first language acquisition alone, as children learn the language of their home locality in the first place. Syntax geography provides compelling evidence for (mature) speakers' adoption of structural traits of their neighbours' language. See for example the Dutch syntactic landscape, well studied by the Meertens Instituut's Syntactic Atlas of Dutch Dialects SAND (ed. by Sjef Barbiers et al. 2005)."
} 
Barbiers, Sjef, Hans Bennis, Gunther de Vogelaer, Magda Vos \& Margreet van der Ham, eds. 2005. Syntactische atlas van de Nederlandse dialecten ['Syntactic atlas of the Dutch dialects']. 2 vols. Amsterdam: Amsterdam University Press.

Bauer, Brigitte M. 2004. Vigesimal numerals in Romance: An Indo-European perspective. In Bridget Drinka, ed. Indo-European language and culture in historical perspective: Essays in memory of Edgar C. Polomé. Special issue of General Linguistics 41: 21-46.

Borsley, Robert \& Andreas Kathol. 200o. Breton as aV2 language. Linquistics 38: 665-710. Braune, Wilhelm. 1928. Gotische Grammatik. Halle: Max Niemeyer.

Croft, William. 200o. Explaining language change: An evolutionary approach. Harlow: Longman.

Deutsche Bibelstiftung. 1978. Die Bibel oder die ganze Heilige Schrift des Alten und Neuen Testaments nach der deutschen Übersetzung D. Martin Luthers. Deutsche Bibelstiftung, 1938. Revidierter Text 1975. Stuttgart: Württembergische Bibelanstalt.

García García, Luisa. 2005. Germanische Kausativbildung. Die deverbalen jan-verben im Gotischen. Göttingen: Vandenhoeck \& Ruprecht.

Hagoort, Peter \& Jos van Berkum. 2007. Beyond the sentence given. Philosophical Transactions of the Roval Societv of Great Britain 362: 801-811.

Hamans, Camiel. 1979. Why didn't piel turn into pijl? In Wim Zonneveld \& Fred Weerman, eds. Linguistics in the Netherlands 1977-1979. Dordrecht: Foris, 307-320.

Hamans, Camiel. 1993. Van epicentrum tot episch centrum: Enige notities over distinctieve morfologie. Tabu 23: 63-73.

Hamans, Camiel. 2007. The history of the study of the Dutch diphthongization. Paper presented at the XIX Internationales Kolloquium SGdS/Henry Sweet Society Annual Colloquium. Helsinki/Helsingfors.

Hamans, Camiel. 2008. An early sociolinguistic approach towards standardization and dialect variation. Paper presented at ICHOLS XI, Potsdam.

Hamans, Camiel, Jacek Fisiak \& Ernst Håkon Jahr. 2009. Degrammaticalization and reanalysis. In Piotr Łobacz, Piotr Nowak, Władysław Zabrocki, eds. Language science and culture. Essays in honor of Professor Jerzy Banczerowski on the occasion of his 70 th birthday. Poznań: Wydawnictwo Naukowe UAM, 145-167.

Haspelmath, Martin. 1999a. Optimality and diachronic adaptation. Zeitschrift für Sprachwissenschaft 18: 180-205.

Haspelmath, Martin. 1999b. Why is grammaticalization irreversible? Linquistics 37: 1043-1068.

Hellinga, Wytze Gs. 1938. De opbouw van de algemeen beschaafde uitspraak van het Nederlands ['The construction of the general received pronunciation of Dutch']. Amsterdam: Noord-Hollandse Uitgeversmaatschappij.

Kartschoke, Dieter. 1993. Das Rolandslied des Pfaffen Konrad. Mittelhochdeutsch/Neuhochdeutsch. Stuttgart: Philipp Reclam.

Labov, William. 2007. Transmission and diffusion. Lanquage 83: 344-387. 
Labov, William, Malcah Yaeger \& Richard Steiner. 1972. A quantitative study of sound change in progress. Philadelphia: U. S. Regional Survey.

McCawley, James D. 1968. Lexical insertion in a transformational grammar without deep structure. In Bill J. Darden, Charles-James N. Bailey \& Alice Davison, eds. Papers from the Fourth Regional Meeting, Chicago Linguistic Society. Chicago: Department of Linguistics, University of Chicago, 71-80.

McCawley, James D. 1970. English as a VSO-language. Lanquage 46: 286-299.

Newmeyer, Frederick J. 2003. Grammar is grammar and usage is usage. Lanquage 79: 682-707.

Norde, Muriel. 2006. Van suffix tot telwoord tot bijwoord: De grammaticalisering van tig ['From suffix to numeral to adverb: The grammaticalisation of tig']. Tabu 35: 33-58.

Ramat, Paolo. 1992. Thoughts on degrammaticalization. Linquistics 30: 549-560.

Schmidt, Johannes. 1872. Die Verwandtschaftsverhältnisse der indogermanischen Sprachen. Weimar: Böhlau.

Seiler, Guido. 2006. The role of functional factors in language change: An evolutionary approach. In Thomsen ed. 163-182.

Seuren, Pieter A. M. 1972. Predicate Raising and dative in French and sundry languages. Ms. Magdalen College, Oxford/Linguistic Agency University Trier (LAUT). (Reprinted as Chapter 7 in Seuren 2001.)

Seuren, Pieter A. M. 1982. Internal variability in competence. Linguistische Berichte 77: 1-31. (Reprinted as Chapter 5 in Seuren 2001.)

Seuren, Pieter A. M. 1985. Discourse semantics. Oxford: Blackwell.

Seuren, Pieter A. M. 1995. Notes on the history and the syntax of Mauritian Creole. Linquistics 33: 531-577.

Seuren, Pieter A. M. 1996. Semantic syntax. Oxford: Blackwell.

Seuren, Pieter A. M. 2001. A view of language. Oxford: Oxford University Press.

Seuren, Pieter A. M. 2003. Verb clusters and branching directionality in German and Dutch. In Pieter A. M. Seuren \& Gerard Kempen, eds. Verb constructions in German and Dutch. Amsterdam \& Philadelphia: John Benjamins, 247-296.

Seuren, Pieter A. M. 2004. Chomsky's Minimalism. New York: Oxford University Press.

Seuren, Pieter A. M. 2009. Language in cognition [Language From Within, vol. 1]. Oxford: Oxford University Press.

Thomason, Sarah G. 2007. Language contact and deliberate change. Journal of Language Contact 1: 41-62.

Thomsen, Ole Nedergaard, ed. 2006. Competing models of linguistic change: Evolution and beyond. Amsterdam \& Philadelphia: John Benjamins.

Von Polenz, Peter. 1972. Geschichte der deutschen Sprache. Berlin \& New York: Walter de Gruyter.

Weinreich, Uriel, William Labov \& Marvin Herzog. 1968. Empirical foundations for a theory of language change. In Winfred P. Lehmann \& Yakov Malkiel, eds. Directions for historical linguistics. Austin: University of Texas Press, 95-188. 
Authors' addresses

Pieter A. M. Seuren

Max Planck Institute for Psycholinguistics

PO Box 310

6500 AH Nijmegen, the Netherlands

e-mail: pieter.seuren@mpi.nl

Camiel Hamans

Dutch Delegation PES-group

European Parliament

Brussels/Strasbourg, Belgium/France

e-mail: hamans@telfort.nl received: 28 October 2008

revision invited: 6 February 2009

revised version accepted: 28 February 2009 